\title{
Air pollution, health risks and coping strategies in China
}

Citation for published version (APA):

Wang, L. (2017). Air pollution, health risks and coping strategies in China: addressing the global health challenges. [Doctoral Thesis, Maastricht University]. Maastricht University. https://doi.org/10.26481/dis.20170913lw

Document status and date:

Published: 01/01/2017

DOI:

10.26481/dis.20170913lw

Document Version:

Publisher's PDF, also known as Version of record

\section{Please check the document version of this publication:}

- A submitted manuscript is the version of the article upon submission and before peer-review. There can be important differences between the submitted version and the official published version of record.

People interested in the research are advised to contact the author for the final version of the publication, or visit the DOI to the publisher's website.

- The final author version and the galley proof are versions of the publication after peer review.

- The final published version features the final layout of the paper including the volume, issue and page numbers.

Link to publication

\footnotetext{
General rights rights.

- You may freely distribute the URL identifying the publication in the public portal. please follow below link for the End User Agreement:

www.umlib.nl/taverne-license

Take down policy

If you believe that this document breaches copyright please contact us at:

repository@maastrichtuniversity.nl

providing details and we will investigate your claim.
}

Copyright and moral rights for the publications made accessible in the public portal are retained by the authors and/or other copyright owners and it is a condition of accessing publications that users recognise and abide by the legal requirements associated with these

- Users may download and print one copy of any publication from the public portal for the purpose of private study or research.

- You may not further distribute the material or use it for any profit-making activity or commercial gain

If the publication is distributed under the terms of Article $25 \mathrm{fa}$ of the Dutch Copyright Act, indicated by the "Taverne" license above, 


\section{SUMMARY}




\section{Summary}

China has experienced a high-speed urbanization and socioeconomic development in the past three decades, which brought severe environmental issues. The air pollution issue got people's attention since the outbreak of a few heavy pollution episodes covering large part of China since 2011, which boosted a range of health related research and enhanced the formulation of unprecedented air pollution control strategies. Evaluating the progress and the challenges of those strategies and their health benefit can help to improve the efficiency of the strategies for the next stage, and to formulate more strategic health based prevention and precaution policies. On the other hand, this highly depends on a deep understanding on the association between air pollution and health, particularly on how the socioeconomic and individual characteristics influence this association and thus to protect the more vulnerable groups.

This dissertation provides a series of separate scientific articles that address the relationship between air pollution and health, and air pollution coping strategies in the context of China. The overarching aims and objectives of this dissertation are three-fold:

1. to explore the influence of air pollution to health, with the stratification of regional economic development and individual characteristics, and thus to identify the regional differences and the susceptible groups;

2. to assess the contribution of air pollution control policies to public health and vice versa based on European experiences;

3. and in the end, to identify the progress and the challenges that hinder the fully enforcement of the air pollution control strategies in China, with specific focus on the two major emission sources, industry and transportation.

Chapter 1, the general introduction to this thesis, presents a general background of the urbanization, air pollution and related health risks in China and the EU. This includes a brief review of the air pollution and control strategies with special focus on China, a summary of the health consequences of air pollution and the major mechanisms of the air pollution influencing health, and the parallels and potential solutions to address air pollution and protect health in both China and the EU. 
Research aims and the content of this dissertation are also displayed in this chapter.

Identifying the regional differences and the susceptible groups are crucial for health protection and precaution strategies as those groups are exposed with higher risks. Accordingly, Chapter 2 and Chapter 3 answer the questions on "how" and "to what extent" air pollution is influencing health and what are the differences of those influences under the varied regional socioeconomic backgrounds; and clarifies the regional differences and the vulnerable groups. Using the geographical weighted regression model (GAM), Chapter 2 identifies the regional differences of air pollution influencing health, and discussed the potential influence of socioeconomic factor to the association between air pollution and health. Spatial correlations between life expectancy and air pollutants were more obvious in south China. Methodology-wise, this was the first study analysing the relationship between air pollution and health at spatial level in China. Chapter 3, on the other hand, explores the health risks of ozone using time-series study. Susceptible groups for mortality caused by cardiovascular and respiratory diseases to ozone exposure were identified as the elderly (65 years and older) and the male.

Chapter 4 indicates the necessity of knowledge transferring between research and policy, and provides the possible methodologies for health impact assessment of air pollution control policies. Using a systematic review, the health benefit of the interventions used to control air pollution in the EU was assessed and its influence to health equity was discussed. Four groups of strategy types were identified: general regulations on air quality control, road traffic related emission control interventions, energy generation related emission control interventions, and greenhouse gas emission control interventions for climate change mitigation. All of those strategies resulted in improvement in air quality and subsequently in public health. Health benefits were gained either as a direct, intended objective or as a cobenefit from all of the strategies, indicating that there was a strong case for promoting Health in All Policies (HiAP), which WHO is facilitating. The methodology for health impact assessment and related health indicators were also discussed to provide reference for further research.

In 2013, the Chinese government launched the - so far - strictest air pollution control plan "Air Pollution Prevention and Control Action Plan" (2013-2017), 
represented a new stage of air pollution control of "improvement phase". Under this circumstance, exploring the implementation progress of this action plan and the sustainability of the plan is crucial for a more coherent strategic approach in the next stage. Chapter 5 illustrates the progress and challenges that hinder the full implementation and the sustainability of the air pollution control strategies. The results indicate that the air quality has improved with the recent air quality control strategies but the improvement is geographically uneven, and significant challenges remain with regard to transportation, industrial emissions control and regional collaborations. More specifically, these challenges are: incapacity for the supervision and monitoring, inter-regional contradictions caused by strong topdown enforcement, and the huge social cost such as unemployment and social inequity. There are many factors causing these challenges. Firstly, the challenges deeply lie in prioritizing the economic development over the environmental protection, which is still the case in many local places. Furthermore, the challenges lie in the insufficient participation and supervision from research and related stakeholders, including central-local government levels and sectional levels. Finally, the challenges lie in the lack of a powerful and explicit legal system, for the contradictions between environmental protection and economic development, between the regional and central government interests, and between the local government and industries. Suggestions are provided in terms of better formulating and implementing of air pollution control strategies in China.

Chapter 6 provides a general summary and discussion of the findings from the former chapters, discusses the added value of the thesis and the potential directions for next step in terms of research, and then illustrates the implications of this thesis to both research and decision-making on air pollution control and air pollution related health studies. 


\section{Samenvatting}

China heeft de afgelopen drie decennia een grote verstedelijking en sociaaleconomische ontwikkeling doorgemaakt, wat een ernstig verslechterd milieu heeft opgeleverd. Sinds de uitbraak van een aantal periodes van zware vervuiling in een groot deel van China vanaf 2011, heeft het probleem van luchtvervuiling de aandacht getrokken. Dit heeft meerdere gezondheidsgerelateerd onderzoeken gestimuleerd en er zijn niet eerder voorgekomen controlestrategieën ten aanzien van luchtverontreiniging geformuleerd. Het evalueren van de voortgang en de uitdagingen van deze strategieën en hun gezondheidsvoordeel kan bijdragen aan zowel het verbeteren van de efficiëntie van de strategieën voor de volgende fase, als aan het formuleren van meer strategische op gezondheid gebaseerde preventie- en voorzorgsmaatregelen. Dit is echter sterk afhankelijk van het begrijpen van het verband tussen luchtvervuiling en gezondheid, met name over hoe de sociaaleconomische en individuele kenmerken dit verband beïnvloeden om kwetsbare groepen te beschermen.

Dit proefschrift omvat een reeks afzonderlijke wetenschappelijke artikelen die betrekking hebben op de relatie tussen luchtvervuiling en gezondheid en beheersingsstrategieën ten aanzien van luchtvervuiling in China. De overkoepelende doelstellingen van dit proefschrift bestaan uit drie onderdelen:

1. het onderzoeken van de invloed van luchtvervuiling op de gezondheid. Met stratificatie van regionale sociaaleconomische posities en individuele kenmerken, om de regionale verschillenen de gevoelige groepen te identificeren;

2. het onderzoeken van de kennisoverdracht tussen beleid en onderzoek en het beoordelen van de bijdrage van het controlebeleid ten aanzien van luchtverontreiniging aan gezondheid en vice versa op basis van Europese ervaringen;

3. en als laatste, het identificeren van de vooruitgang en de uitdagingen die de volledige uitvoering van de controlestrategieën ten aanzien van luchtverontreiniging in China belemmeren, met een focus op de twee belangrijkste bronnen van verontreiniging, industrie en vervoer. 
Hoofdstuk 1, de inleiding van dit proefschrift, presenteert een algemene achtergrond van de verstedelijking, luchtvervuiling en gezondheid in China en de Europese Unie (EU). Dit omvat een korte bespreking van de strategieën ten aanzien van luchtvervuiling en controle, specifiek gericht op China, een samenvatting van de gevolgen voor de gezondheid van luchtvervuiling en de belangrijkste mechanismen van luchtverontreiniging die de gezondheid beïnvloeden, en de parallellen en mogelijke oplossingen om luchtvervuiling aan te pakken en gezondheid in zowel China als de EU te beschermen. Ook worden de onderzoeksdoelstellingen en de inhoud van het proefschrift in dit hoofdstuk weergegeven.

Het identificeren van de regionale verschillen en de gevoelige groepen is cruciaal voor zowel de bescherming van de gezondheid als voor voorzorgsmaatregelen, omdat deze groepen aan hogere risico's worden blootgesteld. Hoofdstuk 2 en hoofdstuk 3 beantwoorden daarom de vragen over "hoe" en "in hoeverre" luchtvervuiling de gezondheid beïnvloedt en wat de verschillen van die invloeden zijn tussen de verscheidene regionale sociaaleconomische achtergronden, en verduidelijkt de regionale verschillen en kwetsbare groepen. Hoofdstuk 2 identificeert de kwetsbare regio's en bespreekt de mogelijke invloed van sociaaleconomische factoren op de relatie tussen luchtvervuiling en gezondheid. Ruimtelijke correlaties tussen levensverwachting en luchtverontreinigende stoffen waren evident in Zuid-China. Methodologisch gezien was dit de eerste studie die de relatie tussen luchtvervuiling en gezondheid op ruimtelijk niveau analyseerde, gebruik makend van het "geographical weighted regression model" (GAM). Hoofdstuk 3 onderzoekt juist de gezondheidsrisico's van ozon met behulp van een tijdreeksstudie. De groepen die gevoelig waren voor sterfte veroorzaakt door harten-vaatziekten en ademhalingsziekten vanwege de ozonblootstelling werden geïdentificeerd als ouderen (65 jaar en ouder) en mannelijk.

Hoofdstuk 4 duidt de noodzaak van kennisoverdracht tussen onderzoek en beleid aan en biedt mogelijke methodologieën om de impact van het controlebeleid ten aanzien van luchtvervuiling op gezondheid te beoordelen. Met behulp van een systematische review werd het gezondheidsvoordeel van de interventies om luchtvervuiling te beheersen beoordeeld en de invloed ervan op de (on)gelijkheid op gezondheidsgebied besproken. Vier verschillende groepen van strategieën werden geïdentificeerd; algemene regelgeving omtrent controle van luchtkwaliteit, 
controle interventies ten aanzien van uitstoot van verkeer, controle interventies gerelateerd aan de uitstoot door het genereren van energie, en controle interventies omtrent de uitstoot van broeikasgas voor vermindering van klimaatverandering. $\mathrm{Al}$ deze strategieën hebben geleid tot verbetering van de luchtkwaliteit en daarmee tot verbetering van de volksgezondheid. Gezondheidsvoordelen werden verkregen ofwel als directe, beoogde doelstelling ofwel als bijkomend voordeel van al deze strategieën. Dit laat zien dat er een sterke zaak was voor het promoten van "Health in All Policies" (HiAP), gefaciliteerd door de Wereldgezondheidsorganisatie (WGO). De methodologie voor het beoordelen van de gezondheidsimpact en verwante gezondheidsindicatoren werd ook besproken om meer naslag te bieden voor verder onderzoek.

In 2013 lanceerde de Chinese regering het strengste controleplan tegen luchtverontreiniging "Air Pollution Prevention and Control Action Plan" (2013-2017), dat een nieuw stadium van controle op luchtverontreiniging vertegenwoordigde als "verbeteringsfase". Onder deze omstandigheden is het voor een meer samenhangende strategische aanpak in de volgende fase cruciaal om de voortgang van de implementatie van dit actieplan en de duurzaamheid ervan te onderzoeken. Hoofdstuk 5 illustreert de voortgang en uitdagingen die de volledige implementatie en de duurzaamheid van de controlestrategieën ten aanzien van luchtverontreiniging belemmeren. Uit de resultaten blijkt dat de luchtkwaliteit verbeterd is met de recente controlestrategieën, maar dat de verbetering geografisch ongelijk verdeeld is. Er blijven aanzienlijke uitdagingen met betrekking tot vervoer, uitstoot door industrie en regionale samenwerking. Meer specifiek gaat het om de volgende uitdagingen: onbekwaamheid in toezicht en monitoring, interregionale tegenstellingen veroorzaakt door sterke top-down uitvoering, en de enorme sociale lasten zoals werkloosheid en sociale ongelijkheid. Er zijn vele factoren die deze uitdagingen veroorzaken. Allereerst zijn de uitdagingen diep geworteld in het prioriteit geven aan de economie ontwikkeling in plaats van bescherming van het milieu, hetgeen in vele lokale plaatsen nog steeds het geval is. Verder liggen deze uitdagingen in de onvoldoende deelname en toezicht van onderzoek en gerelateerde belanghebbenden, waaronder centralelokale overheidsniveaus en sectieniveaus. Tenslotte liggen de uitdagingen in het ontbreken van een krachtig en expliciet rechtsstelsel, ten aanzien van de tegenstrijdigheden tussen milieubescherming en economische ontwikkeling, 
tussen de regionale en centrale belangen en tussen de lokale overheid en de staatsbedrijven. Er worden suggesties gegeven voor het beter formuleren en implementeren van controlestrategieën ten aanzien van luchtverontreiniging in China.

Hoofdstuk 6 geeft een algemene samenvatting en bespreking van de bevindingen uit de eerdere hoofdstukken, bespreekt de toegevoegde waarde van het proefschrift en de mogelijkheden voor vervolgonderzoek. Ook worden de implicaties van dit proefschrift voor zowel onderzoek als besluitvorming over luchtverontreiniging gerelateerde gezondheidsstudie. 
总结

城市化是与社会经济和环境的发展融为一体的。过去的三十年, 中国经历了快 速的城市化和社会经济的发展，同时也带来了严重的环境问题。自 2010 年底以来， 几次大范围的严重的空气污染事件, 将中国空气污染问题带入了人们的视线。伴随 着大量的空气污染健康有关研究, 这些污染事件同时也加速了我国在空气污染预防 与控制方面的政策出台。对这些政策的进展和面临的挑战进行评估能够对下一阶段 (十三五 ) 提高我国的空气污染控制效率提供良好的借鉴。评估这些大气污染控制 政策带来的健康效益，能够促成更具有战略意义的健康预防和保护措施。而这些评 估的实施很大程度上依助于对空气污染健康效益的深入研究。更具体来说，大气污 染与健康的关系在不同的社会经济水平和个体特征背景下存在差异性，研究这些差 异性能够帮助确定脆弱区域和脆弱人群，进而对这些高风险人群采取特殊预防和保 护措施，进而获得政策健康收益的最大化。

本论文通过一系列独立的科学文章来阐述空气污染与健康的关系, 并探索了中 国 (以京津冀为研究案例) 近阶段大气污染防治行动计划的执行进展和面临的挑 战。此论文共有三个总体目标：

1. 研究空气污染与健康的关系。通过纳入区域社会经济水平等因子, 确定空气 污染与人群健康风险关系在空间上的差异性，确定脆弱区域; 通过时间序列 模型, 确定空气污染和人群健康风险关系在个体特征方面的差异性, 确定脆 弱人群;

2. 确定我国近期出台的空气污染预防与控制策略的进展和挑战。对京津冀地区 在主要污染排放源 (工业和交通) 方面进行的污染排放控制措施进行评估, 分析了其存在的问题、面临的挑战和政策的可持续性并提出建议;

3. 探索空气污染决策的健康效益。基于欧洲的经验，评估空气污染控制策略的 健康收益和健康均衡收益。并探讨空气污染政策的健康收益评估方面的研究 方法和健康指标，为空气污染控制政策提供更好的科学依据。 
第一章首先介绍了中国和欧洲城市化进程和其背景下的空气污染状况，随后参 考大量流行病学研究, 介绍了空气污染对健康的影响并展示了不同空气污染物对健 康的主要影响机制。同时进一步阐述了我国在大气污染控制方面采取的措施。鉴于 欧洲曾经 (甚至现在) 面临严重的空气污染问题，且在空气污染控制方面积累了较 多的经验，本章节同时提出了中国和欧洲在空气污染控制方面和健康风险应对方面 存在的差异性和相似性。章节的最后提出了本论文的研究目的和研究内容。

确定脆弱区域和脆弱人群对于制定空气污染预防和控制措施来说至关重要。相 应的，第二章和第三章回答了空气污染在空间和时间维度如何影响健康及其对健康 的影响程度。第二章采用了地理加权回归模型，确定了空气污染健康风险在空间维 度的差异性，并探讨了社会经济水平对此差异性的影响。结果表明，空气污染对预 期寿命和长寿人群的影响在中国西南部更为明显，而这些地方的污染水平相对较 低, 社会经济发展水平相对较低。从方法学上来说, 这是初次研究空气污染与健康 在空间上的相关性。第三章以深圳为研究区域，采用时间序列分析了臭氧对呼吸系 统和心脑血管死亡率的影响。通过校正气象条件和其他污染物因子后，结果表明老 年人 ( 65 岁以上) 和男性对臭氧的敏感度明显高于其他人群。

第四章采用系统综述，评价了欧洲近期大气污染控制政策的健康效益和健康均 衡收益。指出了将科研成果转换为政策并将政策服务于健康的研究的必要性和重要 性。该研究将近期欧洲主要的大气污染控制划分为总体污染物排放控制政策、交通 污染排放控制政策、能源有关污染排放控制政策和缓减气候变化控制温室气体排放 政策。无论作为直接效益还是间接效益，此四类政策均获得了中度和良好的空气质 量提升和相应的健康收益。表明在大气污染控制中，有潜力也有可能采纳世界卫生 组织提倡的“所有公共政策皆将健康纳入考量 ( Health in All Policies )”。该章节进 一步讨论了空气污染控制政策进行健康效益评估研究中的健康指标选取和研究方 法。该章节通过对欧洲近期空气污染治理政策及健康效应的系统研究，为中国空气 污染治理提供理论和实践的借鉴。 
自 2013 年以来，中国政府颁布了自此为止最为严格的大气污染控制方法“大气 污染防治行动计划（2013-2017) ”, 将中国大气污染防治带入了一个“提高阶段”。在 此背景下, 探索该行动计划的执行进展和其持久性对我国下一阶段的大气污染防治 至关重要。第五章阐述了行动计划在京津冀地区的执行情况和遇到的挑战。研究结 果表明: 空气污染防治行动计划改善了区域空气质量，但其效果有限且区域分布不 均衡。在交通和工业污染排放控制方面和区域协作污染控制方面，仍存在大量挑 战。更具体来说，这些挑战包括：执行层面的监测和监督不力; 因利益不均和强制 执行而导致的潜在的区域冲突; 巨大的社会成本，包括失业和社会不公平。导致这 些挑战的因素有很多。首先, 地方政府在执行污染控制行动中将经济发展远凌驾于 环境保护之上。其次，政策的制定和执行过程中，利益相关方（包括各级政府层面 和部门层面) 的参与度不够。最后, 虽然空气污染控制直接的法律法规都已充足, 但缺乏强有力且细化的法律法规来明确不同利益相关方的权责, 特别针对经济发展 与环保的冲突、地方政府之间的利益冲突、政府与企业之间的利益冲突。文章最后 为制定良好的决策和执行方式提供了意见。

第六章总结并讨论了前五章的研究成果, 阐述了各章节在空气污染和健康研究 领域的附加价值，并提出了本论文对空气污染和健康领域在科研和决策方面的影响 和意义。 